\title{
Commercial Policy under Ulèëbalangs. A Factor Contributing to Cumbôk War
}

\author{
Syukri Rizki* \\ Johann Wolfgang Goethe-Universität Frankfurt am Main, Germany
}

Ikhwan Rahmatika Latif

Universitas Muhammadiyah Yogyakarta, Indonesia

\begin{abstract}
Adat chiefs in Aceh - locally termed as uleeëbalang - served as one of the three most compelling socio-political forces besides the sultan and ulamas. As regional rulers in the Aceh Kingdom, they were appointed as leaders through the approval of the Sultan of Aceh. The uleeëbalangs would possess leadership with the reinforcement of a Sarakata letter affixed with a "Cap Sikureueng" (Kingdom of Aceh's Seal). Not only did ulëëbalangs serve as the ruler in terms of Executive administration, but also controlled almost all life sectors of the Acehnese people like trade, court, agriculture and plantation, which the Sultan hardly ever touched. With this legitimate power, the uleëbalangs were rightful to issue commercial policies in their regional territories. In exercising their power, they often acted recklessly towards their subjects. The objective of this study was to identify whether the commercial policy imposed by the uleeëbalangs was one of the factors contributing to the happening of the Cumbôk war in 1945. This study mainly focused on uleeëbalangs who ruled in the Pidie area by studying secondary data available online and offline. The findings of this study confirmed that it was evident that the uleëbalangs' malfeasance in controlling commerce, among other things, did contribute to the tension arising between ulamas and ulëëbalangs, which eventually broke out as the Cumbôk war.
\end{abstract}

Keywords: Uleëbalangs; commercial policy; ulamas; Pidie; Cumbôk war

\section{Introduction}

There was a particular market policy observed in the epoch of Acehnese uleëbalangs. Ulèëbalangs - in a more commonly known Indonesian term is hulubalang - are those appointed by the sultan to reign regions in the capacity as adat chieftains (Alfian, 1975, p. 28), or also dubbed as royal groups (Insider, 1950, p.7). They were controversial figures throughout Aceh history. On the one hand, they are - due to the limited power of sultan to keep an eye on all Acehnese people across other regions under the Aceh sultanate - officially appointed by the sultan to take care of the implementation of adat, yet, on the other hand, their malfeasance and misuse of authority aroused the subjects', especially the ulamas', displeasure towards them (ibid. p. 8).

\footnotetext{
* Corresponding email: syukririzki@gmail.com
} 
Of the reported uleeëbalangs' misuses of authority is the commercial policy they impose, that is, how they control, or more precisely monopolize, markets in the districts under their leadership (Alfian, 1975, p.30). This power had much to do with their collaboration with the Dutch. The security granted from the Dutch allowed them to own a large scale of lands, as well as to receive less sanction in case their gross misconduct is complained and sued by their subjects (ibid.)

The current paper seeks to investigate how uleëbalangs controls commerce and how the commoners react towards them, and how both groups were involved in Cumbôk war. Document analysis is employed on the secondary data, which are collected from various relevant sources accessible online and offline.

In this regard, such a massive impact of the war has already attracted some scholars. Ratna (2005) performed a research entitled Perang Saudara di Aceh 1945 in which she discussed that there was a horizontal conflict between ulèëbalangs and ulamas triggered by a different political collaboration of the two groups of colonizers: the Dutch and Japan. Collaboration between the Dutch and uleëbalangs was deemed 'haram' by ulamas, while Japan's collaboration with ulamas resulted in important positions of ulamas in society.

Similarly, in her research, Kurniawati (2008) found that the Indonesian independence proclamation on 17 August 1945 largely corroborated the polarization between ulamas and uleeëbalangs. While ulamas highly credited Indonesian independence, uleëbalangs had an endured fondness of the Dutch to return. They even established the so-called Comite van Ontvangst (a committee to welcome the Dutch) for the sake of their power resumption. In the aftermath of Japan's defeat in World War II, which resulted in Indonesia's independence proclamation, it planned to hand the weapons to Acehnese people. Both ulamas and uleëbalangs unyieldingly insisted on receiving the weapons, hence the inevitbale bloody battle between the two groups in Sigli on 4 October 1945.

Another study was carried out by (Agustiningsih, 2007). She found out two factors triggering the Cumbôk war. The first is the suspicion prevailing among uleëbalangs and ulamas since the later insisted on rectifying the corrupt jurisdiction practiced by uleëbalangs. The second is the divide et impera strategy played by the Dutch that positioned ulëëbalangs as the group that confirmed the colonizer's sovereignty on Aceh, making ulamas at the same time regard them as traitors. The rivalry tension was intensified as ulamas united by forming All-Aceh Religious Scholar Association (PUSA), which then gained a good degree of trust from Japan. The war which was won by ulamas did bring an end to the centuries-long ulèëbalangs' feudal domination.

The discussions of the three aforementioned studies were very much about the political power dynamics among uleeëbalangs and ulamas during the Dutch and Japan colonization. These two groups' confrontation was explained as the efforts to dominate the important political positions in Aceh. Both attempted to justify their rightfulness to determine the Aceh's leadership after the Indonesian independence's proclamation. However, the present paper attempts to zoom in on the economic factor, which , as pointed out by Deraniyagala $(2005$, p. 61) plays a significant role in creating material conditions that trigger a civil war. It identifies the features of uleeëbalangs' commercial practice before the Cumbôk war.

Based on this, besides other factors like the imperialism of Dutch and Japan and the talebearing of the communists, this paper attempts to answer the question "did improper commercial policy exercised by ulëëbalangs also serve as a factor that spawned the Cumbôk war?"

After briefly sketched an introduction followed by mentioning some previous studies and limitation of the discussion, this paper then elucidates the historical account of uleëbalangship, describes the Cumbôk war in the light of the fall of the uleëbalangs' aristocracy, and eventually concludes. 


\section{Scope of Discussion}

Ulëëbalangs were scattered all over Aceh, bestowed authority to seize control over their people. Each of them might likely promulgate different policies to be carried out by the members of their communities. To thoroughly investigate this requires an exhaustive analysis and quite an extended period. Accordingly, in order to narrow the discussion and to capture a clear image of an occurrence, the present paper only scrutinizes the ulëëbalangs' commercial motives which are attributed to the cause of the Cumbôk war'.

The factors contributing to the happening of Cumbôk war has attracted many researchers to study. The war constitutes a turning point that brought about some alterations during Acehnese society. That the ulëëbalangs' influence was substantially diminished, their properties were confiscated, and they were compelled to give up their positions in civil government and Indonesian military are of the instances of the changes ensuing after the war (Daud, 2006, p. 6). Based on this, this paper aims at emphasizing that besides other factors e.g., the imperialism of Dutch and Japan and the talebearing of the communists, improper commercial policy imposed by the uleeëbalangs also served as a trigger of the Cumbôk war, marking an unforgettable turning point in Aceh society. This so since the so-called "horizontal inequality" between regions and groups can be a severe factor that may induce violent conflict in a society (Humphreys, 2003). Focusing on improper commercial policy is essential since, despite the administrative function of uleëbalangs, their obsession with a financial gain is very vivid. Additionally, their existence marked no unity of their people since the mere objective was to earn income, which mainly can be collected through their control on streets in their regions (Siegel, 1969, p. 15 - 16).

Accordingly, to arrive at comprehensive findings and conclusion, an ample methodology is worth serious consideration.

\section{Methodology}

This research is qualitative descriptive research, where the author attempts to garner data as much as possible that enables him to capture all of the elements of an event; those elements are used to make the event as that it is (Sandelowski, 2000, p. 39). For this sort of study, the data can be collected through observation of the targetted event and an examination of documents and artifacts (ibid. p. 338). In this case, the collecting of the data and the analysis can be executed concurrently (ibid.).

The present research is also primarily library research. Abott $(2008$, p.11) pointed out that "Il]ibrary research is the art of figuring out which of the many things that are staring you in the face is the one you ought to have wanted to look. It has almost nothing to do with searching for known items". This defnition shortly suggests that the significance of performing library research is to study an undetermined number of sources to discover answers for a specific research question.

So, for this study, by trawling through a large number of sources, both those accessible offline and online, necessary data can be collected then elicited as information to answer the raised research question.

\footnotetext{
${ }^{1}$ Cumbôk is now situated in the sub-district of Sakti, Pidie. Its ulèëbalang before the Indonesian independence proclamation was Teuku Muhammad Daud - or commonly renowned as Teuku Cumbôk (El-lbrahimy, 1982, p. 87). Cumbôk war denotes the sequence of battles occurring in Pidie from 2 December 1945 to 16 January 1946 (Daud, 2006, p. 63-67). It was the battle between ulamas - who were for the Indonesian independence proclamation - and the ulèëbalangs - who were for the Dutch's return to rule in Aceh.
} 


\section{Historical Account}

Ulèëbalangs are, as termed by Hurgronje (1906, p. 88), the 'lords of the country'. The term essentially suggests that these people were military leaders bestowed right from the sultan to monitor the troops on their district (ibid.). Reportedly, the sultan did not create their position but rather confirmed their existence (ibid.). Stated another way, although the title 'ulëëbalang' allegedly emerged around the premises of the court in Banda Aceh, their authority had long existed beforehand.

In dealing with the uleeëbalangs, the sultan was very circumspect as he considered that it was imperative to respect the powerful potentates around his sultanate. In other words, although the sultan possessed the de jure authority to reign the entire Aceh, he, in practice, only directly controlled the capital and the royal palace (Uddin, 2009, p. 616).

Formerly, the uleeëbalangs ever claimed that pursuant to Adat Meukuta Alam², they did not have to hold letters patent of the Sultan to verify their position, for they could claim that they inherited the authority from their forefathers (Hurgronje, 1906, p. 88). However, later on, such letters patent at fact played a notable role for the uleëbalangs to stress their power and rank (ibid., p. 89).

Uleëbalangs are those who predominantly took direct control over the people they lead in smaller regions, and even the sultan himself could successfully gain his throne after winning their consensus (ibid.: 618; Hurgronje, 1906, p. 90).

Outside the actual sultanate territory are confederacies of ulëëbalangs called sagoe (angles). Several mukims that united formed a sagoe named after the number of mukims it collects, e.g., the XXII Mukim, the XXVI Mukim, and the XXVMukim. Such distribution of sagoe was reportedly started under the leadership of Sultanah Nakiatuddin, who reigned from 1675 to 1677 (Hurgronje, 1906, p.90).

Further, there were several conditions in which someone can be considered as an ulëëbalang. The first type of ulëëbalang is that the so-called Panglima sagoe ${ }^{3}$. Excellent characteristics were what matters when it came to shoulder a position for an uleëbalang who serves as a Panglima sagoe. Therefore, despite heritability of the authority, a Panglima sagoe might not attain any position in case his fellow potentates did not recognize his leadership (Hurgronje, 1906, p. 92). Besides Panglima sagoe, there were two other sorts of uleëbalangs during the Aceh sultanate viz. the so-called uleeëbalang poteu and the unrecognized ulèëbalang. The former were those trusted to hold a position in the Sultan's territory, or those receiving the title from royal favor, or those appointed relevant post at Court (Hurgronje, 1906, p. 92). Meanwhile, the latter were those allegedly only adapting the title 'ulëëbalang' as a designation to their rank motivated by the pride they might have by doing so; consequently, other ulèëbalangs who denigrated these aspirants -irrespective of their true receiving of the title or merely their arrogance - said that they were merely keujruens or meuntroes.

Henceforth, as the expectedly trusted representatives of the sultanate to ensure the practice of Acehnese adat, ulëëbalangs' role in controlling commerce is much more apparent and repeatedly mentioned in Aceh history.

\section{The Commerce Under Ulèëbalang}

Since the sultan cannot fully watch all regions, he rules all over Aceh, outer spaces out of the royal palace should be under the uleëbalangs' monitoring. This limitation enabled the uleëbalangs to directly transact with foreign traders who moored their ships to the ports around the uleeëbalang' territory

\footnotetext{
${ }^{2}$ Surmised to be issued by Sultan Iskandar Muda, Adat Meukuta Alam constitutes a collection of royal edicts which completed the previous edicts of previous sultans. It harbors basic regulations of a country such as government system, power deviding, and rules of institutions in a country and so on (Chambert-Loir, 2017, p. 72; Hasjmy, 1977, p. 129).

${ }^{3}$ A Panglima sagoë is one of the official officers in Aceh society. He is appointed to rule a sagi (parish) outside the actual sultanate palace territory (Hurgronje, 1906, p. 89).
} 
(Uddin, 2009, p. 618). That is why these district rulers tended to ignore the supreme leader above them and impose their policies on the subjects they govern.

On the one hand, indeed, since its first founding in the $16^{\text {th }}$ century - precisely in 1520 , Aceh sultanate's development was characterized by its endeavor to reign the whole regions across Aceh. On the other hand, the counterhegemonic movements provoked ulèëbalangs in the regions infallibly worked to dispose of the sultan's authority (Ismail, 1991, p. 38). Although the sultanate's authority over the ruled regions was once emphasized during the epoch of Sultan Al-Qahar and Sultan Iskandar Muda from the end of the $16^{\text {th }}$ century to the beginning of $17^{\text {th }}$ century, it relapsed into the weak condition during the next rulers' reign. It was precisely in 1629 when Aceh's marine force was defeated during the offensive against Malacca, bringing about the termination of Sultan Iskandar Muda's reign in 1636 (ibid., p. 38-39). Ever since, owing to the sultanate's fragile power from the mid-17th century to the end of the 18th century, there was no firm control on uleëbalangs (ibid., p. 39); hence, the rising of their autonomous decision making.

Such a mode of unregulated trade was not also craved by uleëbalangs but also by international traders because it was perceived more profitable and convenient. The reason for this was mainly the preference of some merchants in Penang who demand unhampered commerce with Aceh (Wong \& Lee, 2014, p. 176). Further, the demand led to the opening of the west coast of Aceh as the primary region to cultivate pepper; Leube Daffa and Leube Kontee were two renowned ulëëbalangs to rule the 'pepper' district (ibid.). In the $18^{\text {th }}$ century, Aceh was perceived as a strategic area by Western powers such as British, Dutch, and French. More impressive is that for the British, especially, besides serving as a commercial area, Aceh was regarded as a naval basis by which it might control the Indian Ocean and the Strait of Malacca (ibid.).

Take an example of the Aceh - Penang relation. The trade with Penang constituted the primary source for the royal revenue of the Aceh Sultanate. The British opened port city in 1786 and attracted mainly the Malay traders from the eastern coast of Sumatera and ports along the west coast of the Malay peninsula (Hussin, 2005, p. 216). The British opened the port as an entrepôt from which it collected pepper from Sumatera and Terengganu before re-exported it to China, India, and Europe (Wong \& Lee, 2014, p. 177). This trade development left the court with no other options but to regulate all export and import duties. Again, such an act had to deal with the existing ulëëbalangs' power.

Further, the sultanate's downturn, accompanied by the lust to make an internationally open trade, led the uleëbalangs to perform more. During this time, ulèëbalangs in the beyond-court regions tended not to comply with the centralized authority in Kutaraja. Citing an example, the Leube Daffa mentioned earlier - a successful pepper trader - with his incomes from pepper plantation could ever form his countervailing defense force to refuse the Sultan (ibid., p. 40). The authority was also denied by other regions' ulëëbalangs, including by those in Pidie in 1814 (ibid.), the region where Cumbôk war concentrated, ending the aristocrats' heydays.

Pidie was one of the leading pepper suppliers demanded by the market in Penang. It was one of the most targeted ports - besides Mergui, Tenesserin, Pegu, Junk Ceylon, and Melaka - by international traders who came from the ports in the Coromandel coast after their dropping by and passing Penang (Hussin, 2005, p. 225). Moreover, before the late 1800s, for Penang, Pidie made an up-and-coming trading partner since the later possessed hinterlands which produced and exported mainly pepper and betelnuts to the former (ibid., p. 226). Such a strategic opportunity might later with the passage of the time exhilarated the ruling ulèëbalangs in the respective regions around Pidie to directly connect with the coming traders, regardless of the hegemonic power of the sultan.

Controlling the market constitutes the primary source of ulëëbalangs' income. Owning a broader field, charging tolls on the traders passing by the roads in their territories, and leasing the fields for profit are among attributes frequently associated with the mode of ulèëbalangs' trading. They are chiefs 
and traders at the same time, as pointed out by J. Jongejans, a former resident of Aceh, "trade is in the blood of many Acehnese, especially the chiefs and the better situated" (Jongejans, 1939, p. 227).

Not only did the uleeebalangs ignore the supreme authority, but their maladministration was also noticed when they were to handle their subjects' financial affairs. For instance, based on Islamic teaching, there is a particular procedure in dividing inheritances, and uleëbalangs were those responsible for doing this task. Indeed, they could not carry out the task themselves; therefore, they employ their Kalis (officers) - whose fatwa was allegedly adjustable - to divide the shares to the heirs. As a benefit, uleeëbalangs received $10 \%$ as a commission they claim as their right (ha' pra'e) (Hurgronje, 1906, p. 96). Further, they monitored where the shares for the absent heirs go, and yet, reportedly, these shares went unknown (ibid.). Besides, another reported 'outrageous greed' of them was the embezzlement of zakat (religious tithes) for their purposes (Uddin, 2009, p. 620). Lamentably, the subjects who were dependent on them could not do much to contest since uleëbalangs had their vassals who sided with them. Such a submission was even naturally set in the society as noted by Snouck Hurgronje describing an Acehnese behavior towards the aura of uleëbalangs, "he fears them, and it is his natural impulse to bow to superior alone, but to this, he submits unconditionally" (Siegel, 1969, p. 31). Based on numerous reports and publications commenting uleëbalangs, we can say that in general unpraised comportments of ulèëbalangs' leadership outweigh their praised ones.

However, there are some most mentioned egregious narratives typically attributed to uleeëbalangs' conduct. Firstly, the decentralization of commercial policy serves as the main attribute of a commercial policy practiced by uleeëbalangs. Long established was the autonomy of uleëbalangs that the Sultan merely confirmed their power because he should not undermine their authority to maintain his claim of kingship. Evident is that the policy imposed by uleëbalangs is different from district to district. Citing an example, an uleeëbalang of a particular district may determine the crop the farmers should cultivate, e.g., pepper and betelnut, the cost of distribution, and the tax.

The decrease of the sultan's power in the $17^{\text {th }}$ century intensified the reluctance of uleëbalangs to comply with points stipulated on Sarakata ${ }^{4}$ Although it should be the sultan who monopolizes the international trade, ulëëbalangs in their territories did so themselves for their gains. They collected the duty and custom submitted by the international traders and did not forward them to the central authority in Kutaraja (El-Ibrahimy, 1982, p. 73). The fragile sultan's power was more exacerbated by the ulèëbalangs' acts when they use armed boats to pirate British ships and put the blame of the sultan (ibid.). The sultan could not punish them nor prevent their movements nevertheless (ibid.). This dissynergy was even more worsened when uleeëbalangs with armed boats invade the ports of the rivals among themselves, thwarting the importing of pepper and exporting of opium and weapon; this was a continuous war for a period of time, as reported by Van 't Veer (1969, p. 34). This happening led the Dutch to surmise that the Aceh sultanate was not able to secure the maritime trade (ibid.).

Secondly, most ulëëbalang, if not all, heavily depended on the legal authorization of the Sultan. In one sense, uleëbalangs claimed that they inherited their force from their ancestors even without the Sultan; in another sense, they, later on, corroborated their position by showing the letters patent issued by the Sultan. In actuality, however, they move independently, making the message of the Sarakata merely an abandoned formality (ibid.).

Thirdly, it is narrated in history how uleëbalangs depended on the 'mercy' of the Dutch. The Dutch itself regarded uleeëbalangs as the basis of its influence (Reid, 1979, p. 12). It is scarcely an exaggeration to say that uleëbalangs and the Dutch actually grounded a mutualistic relationship, yet not necessarily an interdependence. Besides undermining the authority of the sultan, this sort of relationship even reached an alarming situation that ulëbalangs enacted a salient role in making Aceh

${ }^{4}$ Sarakata denotes royal edicts issued by the sultans of Aceh as an attempt to centralize the authority (Crecelius \& Beardow, 1979, p. 51). 
lose its sovereignty. In due course, the fall of Aceh was caused by, among other factors, the treason of uleeëbalangs. For example, on 9 December 1873, under the lead of Lt Gen Van Swieten, the Dutch troops conquered Aceh thanks to the help of an ulëëbalang named Teuku Nek Meuraxa who concocted a plot so that the colonizers could take over the premise of the palace (El-Ibrahimy, 1982, p. 77). The manifestation of his agreement with the sovereignty of the Dutch was even shown clearer as he and other ulëëbalangs met the sultan in Keumala - a region where he evacuated after the court in Kutaraja was annexed by the Dutch - and suggested him to plan a peace agreement with the Dutch (ibid.).

In this light, no wonder, the lamented conduct of uleëbalangs was also seen as their ignorance to fight the Dutch when Aceh should emphasize its sovereignty during the Aceh War. The author of the extremely renowned Acehnese epic "Hikayat Prang Sabi," Teungku Chik Muhammad Pantée Kulu, strictly criticized their ignorance in which he asserted (Alfian, 1992, p. 38):

\section{"Bek takira keu ulèëbalang, kajipasang le jen pari, he Teungku Cut donya ka akhe, agama tanle sigala nanggri".}

"Do not count the ulëëbalangs, the spirit possesses them, O Teungku Cut the world is about to end, there is no longer religion all over the countries."

Fourthly, it is reported that uleeëbalangs' acts were usurious and illegal. Basically, as chiefs of their people, they should practice ethical conduct when exercising their authority. What showed was that for their gains, they were busy making international trades that the necessities of their subjects did not receive their serious attention. The subjects were even charged with taxes when using the stream of the ulëëbalangs' irrigation water when using roads to distribute goods, and when selling crops in markets managed by the ulëëbalangs (El-Ibrahimy, 1982, p. 74). Usually, no less than $5 \%$ to $10 \%$ of tax was charged on the subjects (ibid.). Additionally, the uleëbalangs possess the right to exploit the commonality in their territory to till and plow their plots and paddy fields without being salaried; this sounds quite similar to the term tillable et corvéable à merci (literally, to be liable to tax and to forced labor at will) during late French feudalism (Revolusi December '45 Di Aceh, n.d., p. 10).

In the same vein, such a practice was once mentioned by Aly Hasjmy, (1977, p. 40) as he quoted the statement of Teungku Chik Abdul Wahab Tanoh Abèe - a renowned Aceh Islamic scholar - when advising the ulëëbalangs who wanted to fight against the Dutch colonizers, "[...] the belongings of the people we have taken because of our lust, we should give them back. The subjects should not always be mistreated and uphold justice first before we demand justice from others. Therefore, do repent before asking the people along to fight the war [...] if what I call for is fulfilled by you, then I will join you to the battlefield. Otherwise, ask me and my pupils not ..... This case, however, confirms that there were still uleeëbalangs who sincerely aspired to struggle against the Dutch, yet had to rethink firstly about the impacts of their leadership suffered by the society members.

Although uleeëbalangs were found across Aceh, those in Pidie had more to do with the Cumbôk revolution (Revolusi Desember '45 Di Aceh, n.d., p. 17). Pidie is the site of the Markas uleeëbalangs, ulèëbalangs headquarter, which received support for weapons from other ulèëbalangs across Aceh. That is why later on after the fall of ulèëbalangship, ulèëbalangs in other Aceh areas also showed their reaction by continuing their struggle against the movement of the hoi polloi. Pidie uleeëbalangs own income from their economic activity and trade. They were more luxurious than those ruling the areas of in west coast of Aceh. They charged tax on the region's main products like areca nut and coconuts grown along the village paths and small plots mostly owned by the uleëbalangs (Siegel, 1969, p. 27).

Noticeably, uleeebbalangs' seizing their power was not unchallenged. The religious scholars (ulamas) - who innocuously did not desire the office nor revenues of the uleeebalangs (Siegel, 1969, p. 49) - were considered as a hindrance who always attempted to find their ways to end the 
ulèëbalangship. While ulëëbalangs' authority is merely concerning the right to reign certain areas, these ulamas got their influence widespread by having a lot of pupils who came to their dayahs (traditional Islamic school) for religious classes. The ulamas' mastery of Islamic knowledge made them the sources of legitimized fatwas and correct understandings and interpretations of the religion's teachings. This is why. after Indonesian independence, their charisma seemed like a threat that might disrupt the existing ulèëbalangs' traditional claim of power. Thus, the people's unsatisfactory towards ulëëbalangs then found its place in the concern of ulamas, hence the unattainable movements calling for the Cumbôk war to happen soon.

The most frequently mentioned figure behind the Cumbôk war is Teungku Muhammad Daud Beureuèh, who founded Persatuan Ulama Seluruh Aceh, All-Aceh Religious Scholar Association (PUSA). Sjamsuddin (1985) mentioned that Tgk. Muhammad Daud Beureuèh might be stirred by his rancor on uleëbalangs who punished his father. Be that as it may, Tgk. Muhammad Daud Beureuèh was a considerably influential figure that contributes to inspire the commoners to fight against ulèëbalangs' feudalism. Instead of letting himself busy with only preaching religious messages on the pulpit or in exclusive forums, the actualization of his concern over the society can be noticed in his daily acts. Take the case of Pidie villagers' damming a swamp for irrigation, which then in the rainy season resulting in a very problematic flood (Siegel, 1969, p. 61-63). The people despaired from the government individuals who did nothing as a solution. Tgk. Muhammad Daud Beureuèh - at that time, was not appointed any position in the government any more - remarkably could lead the people to dig a new channel draining the flood to the Strait of Malacca. By doing so, he did not have to free the lands owned by the people nor pay the laborers. In the name of the religious deed, he could successfully convince them to work together and end the flood problem.

Amid uleëbalangs themselves were those for the commoners, those who were for the Dutch, and those for the ulamas. During this time emerged Tgk. Muhammad Daud Beureuèh, who established an educational institution called Jamiatuddiniyah in Peukan Pidie, Sigli. Thanks to the system of this institution and of the likes of it emerged the generation who were aware of human values and were brave to criticize the practice of ulèëbalangs' feudalism, unlike the other Dutch-backed up era where ulëëbalangs were still reasonably healthy to mute their opponents' voices. Working in various professions in society, the educated men of the institutions mingled with commoners and shared their abhorrence towards uleëbalangs. In 1939, their sounds was more amplified through two weekly newspapers based in Medan - Penyedar and Soeara Kita - yet also circulated around Aceh. Several names reported to have written for the Aceh rubric provided by these media are H. M. Zainuddin, Johan Ahmad, and Hasan Ali. Each of them was identified to use the pen names of De Atjeher, Panyot Tjulet and Sira Campli respectively (Sulaiman, 1990, p. 30). The criticism triggered inconvenience among ulèëbalangs. Their publications revealed and contested the mispractice of uleeëbalangs which they perceived to be contradicting the values of humanity. Considering the region where the journalists came from, Pidie, the criticism was very likely to be made against ulèëbalangs' misconduct in Pidie.

Unlike the power of uleëbalangs which only surround their lands of leadership, ulamas like Tgk. Muhammad Daud Beureuèh could obtain broader range of people sympathy since their influence goes beyond the administrative borders. Ulamas established religious institutions that could collect several study men, irrespective of their regions of origin. Through such institutions, ulamas might inculcate their political insights to get the people awaken about the inherited discriminative behavior of most ulèëbalangs. As a result, the polarization between the followers of ulëealangs and ulamas happened. In November 1945, both were already prepared to fight a war yet awaited for a proper trigger to break out (Safwan, 1992, p. 141). 


\section{Cumbôk War and the Fade of Ulèëbalangs' Influence}

Eventually, the heydays of uleeebalangship gradually faded as the Dutch were forced to leave from Indonesia in the 1940s, followed by the Japanese colonization (Uddin, 2009, p. 624). The three-year Japan colonization lasted until it was defeated in 1945 by the US in the second World War. Indonesia perceived the moment as a proper time to proclaim its independence. Ironically, while ulamas under the All-Aceh Religious Scholar Association (PUSA) led by Tgk. Muhammad Daud Beureuèh showed their excitement knowing the proclamation, uleeebalangs led by Teuku Daud Cumbôk surprisingly showed their haughty attitude towards the proclamation. They deemed that Aceh was not prepared for joining Indonesia's independence and expecting that the Dutch will surely return soon (Arif, 1946, p. 12; Dewanto, 2011, p. 13).

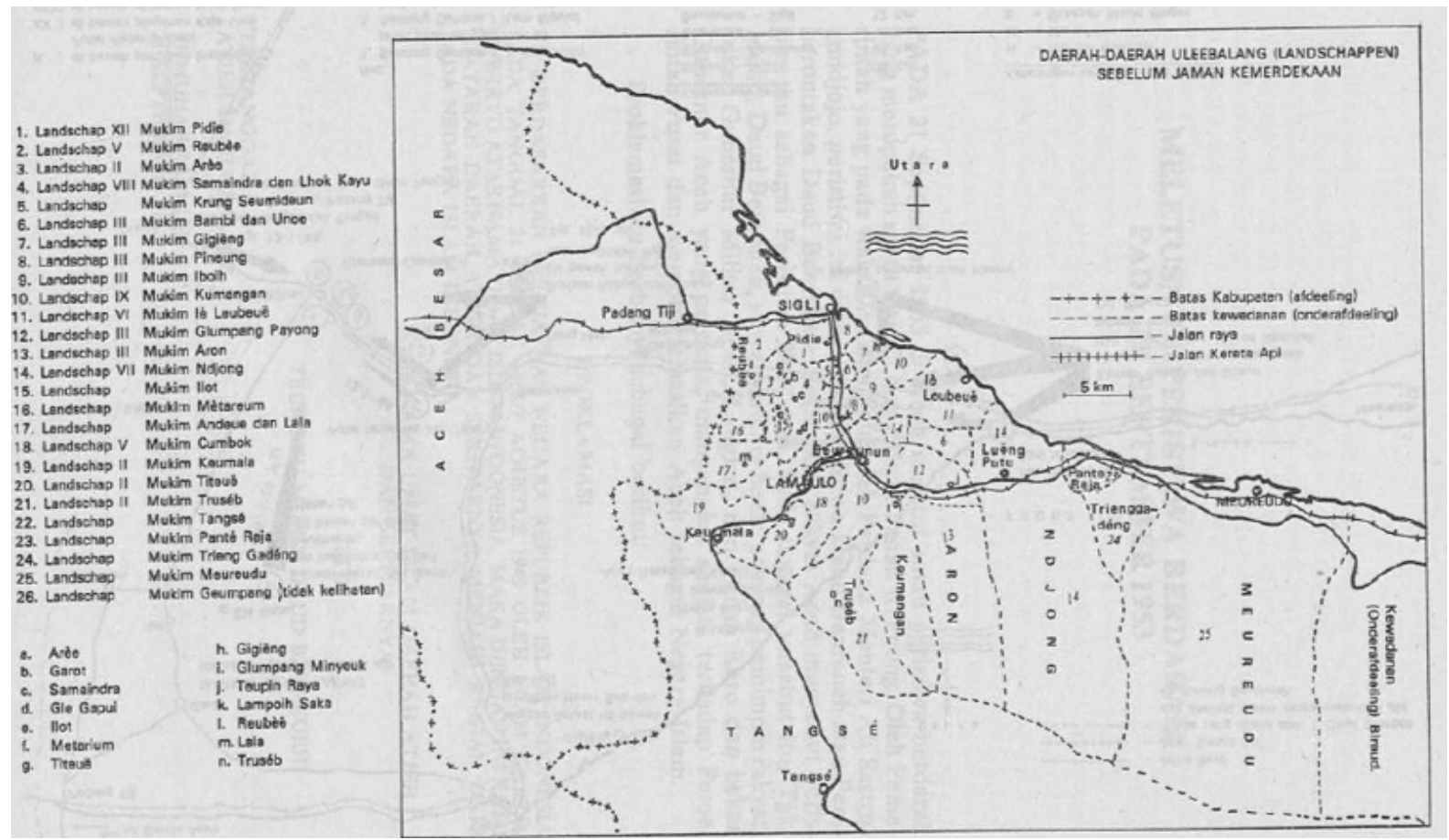

Figure 1. Map of territories of uleëbalangs before Indonesian independence.

(El-Ibrahimy, 1982)

Responding to this, the first Aceh governor, Teuku Nyak Arif, commanded the Col. Syamaun Gaharu to warn the movement of Teuku Daud Cumbôk. Here we can infer that although Teuku Nyak Arif is an ulëëbalang himself - hence his bearing the title 'teuku' - his nationalism was vividly manifested in his acts in ending the tension. Thus, we cannot instantly generalize that all ulëëbalangs were against the national independence and the new central government in Jakarta. Teuku Nyak Arif, Teuku Hamid Azwar and Teuku Ahmad Jeunib were among those who were for the Indonesian statehood (Dewanto, 2011, p. 12).

It seems that Japan understood the existing polarization between ulamas and uleëbalangs and followers of both since the first time they set foot in Aceh. The situation, therefore, should be taken into account in order not to displease both groups and aggravate the unrest. The tactic of dividing the power by appointing ulèëbalangs and ulamas in certain important governmental positions was deemed a proper step to grasp supports. Japan's annexation on Indonesia did not last long but slightly terminated as the US took over Nagasaki and Hiroshima in 1945, marking Japan's defeat and forcing its troops to withdraw. In Aceh, those who were aware of the situation saw an excellent chance to take the weapons. Both militant groups considered themselves rightful to receive the left arms. 
Indeed, Japan's defeat marked the power vacuum in Aceh, resulting in harm situation for the remaining Japanese military across Aceh. Such a transition sparked the unmonitored acts showed by the militant groups, the ulëëbalangs, and ulamas. The former consisted of the uleeerbalangs themselves, their relatives, and Acehnese people who were well served by them during the Dutch colonization. Meanwhile, the later collected religious scholars and the youth who harbored an avenge towards ulèëbalangs, be the motivation was to eradicate the Zelfbestuurder system or to revenge the bad conducts ulëëbalangs did on them (Insider, 1950, p. 8). Again, this tension was immensely intensified in Pidie since the organization of ulamas' movement took its basis in Aree, a village adjacent to Sigli; and the headquarter of ulèëbalangs sits on Cumbôk, Lam Meulo (ibid., p. 9). Both regions were and are situated in Pidie.

The hatred against ulèëbalangs has rooted for a very long time, awaiting a proper moment to explode. It seemed that neither uleeëbalangs nor ulamas were pleased to cease the tension between them with peace, but instead, they prefer 'trial by combat,' which they believe may determine who wins and rules; and who fails and is governed. Knowing this, Japan play a strategy called whispering campaign through which it disseminated narratives among Acehnese, which successfully widened the gap between the fighting groups, distracting the public attention not to shed light on them. ${ }^{5}$

Japan's plan to hand the arms aggravated the burning tension between the commoners - led by Tgk. Muhammad Daud Beureuèh - and ulèëbalangs - led Teuku Daud Cumbôk. Both militant groups claimed the right to receive the arms.

One night in November 1945, in Sigli, ulèëbalangs and their followers conquered Sigli. Then came the followers of ulamas from the outskirts of the town, demonstrating by yelling the name of Allah. Fire shot from inside the city - not known whether or not ulëëbalangs launched it, yet the Indonesian official report confirmed it was - exacerbated the situation that the noise of bullets shot was heard very loudly. This battle terminated after three days and nights resulting resulting in several victims. Even, Tentara Keamanan Rakyat, Civil Security Force (TKR) - the Indonesian national military body that attempted to be in neutral stance - warned the ulëëbalangs to cease their offensive. It can be inferred that the adat leaders were the more severe threat of society, not vice versa. Nevertheless, the battle marked no end of the conflict between the two groups.

The ensuing battles occurred outside the town until two following months with the ulama group as the winners. The way this group sought redress for the prolonged deep loathing towards ulèëbalangship had massively altered the Aceh's political dynamics. For instance, although precisely was concentrated in Pidie, the Cumbôk happening successfully made the ulèëbalangs' power across Aceh fade away. Some of them were forced to give up their power to ulamas, while others voluntarily surrender as they were informed about the defeat of their fellows in Pidie (Insider, 1950, p. 13).

Noticeably, the fall of the uleeëbalangship - marked by the conquering of Lam Meulo town, the ulèëbalangs' center for political and military affairs, by the Indonesian national force on 13 January 1946 - resulted in detrimental narratives about the winner group. A widely held axiom circulating in the society was that Tgk. Muhammad Daud Beureuèh intended to subvert the long-established system of ulèëbalangs' leadership (El-Ibrahimy, 1982, p. 109 - 112). Needless to add, such a narrative is quite typical to run alongside a post-revolution situation where people can easily provoke others and frame public opinion for personal interests, either intentionally or unintentionally.

\footnotetext{
${ }^{5}$ Insider (1950, p. 10) stated that Japan was threatened by some attacks launched by Acehnese on some of their strongholds. By emphasizing the polarization, they might remain unnoticed.
} 


\section{Conclusion}

The description of Acehnese uleëbalangs, their commercial policy, in particular, is like a parallax. At one extreme, on paper, they are the legitimized leaders to rule in the regions, to whom the subjects were the hostile of their willingness, that is, they were repressed to obey. At another extreme, in practice, their authority ran in a decentralized way, which did not depend totally on the policy of the leading power in Kutaraja. If we side with the argument of Hurgronje (1906) who pointed out that ulëëbalangship had long existed before the sultan's influence took effect, it can be inferred that ever since such a feudal diffusion survived the sultanate epoch. It went through the Dutch and Japan annexations, and technically collapsed as affected by the Cumbôk war in early 1946. In this study, it is found that ulëëbalangs did ever implement a specific type of commercial policy, which brought about their subjects' displeasure.

On the whole, ulèëbalangs practiced the decentralization for their commercial policy through which they could determine their own rules on the subjects they led. Notwithstanding, their relying on the sultan's Sarakata, which legitimized their position as the representatives of the sultan's leadership, had successfully emphasized that their authority is confirmed and lawful. A mutualistic relationship they tied with the Dutch enabled them to do more trading activities without being disrupted by the overlordship of the sultan. Also, the ways they charge tax on the commoners and employ them to work with them without being paid, or adequately paid, are seriously considered usurious and illegal acts.

The accumulation of these displeasures was the cause that then broke the Cumbôk war. In this light, the ulamas were the most prominent figures that encourage the subjects to react, that is, to rebel, since, as put on by Burke (n. d. in Tiro, 1999, p. 7), people react not because of the willingness to attack but due to their losing patience.

Of the ulamas was Tgk. Muhammad Daud Beureuèh, who established the education institution to educate the people about the values of humanity. Later on, these educated people's bravery to express the discontent on media noticeably brought about a massive edification. Concentrating in Pidie district, Tgk. Muhammad Daud Beureuèh did lead the people to partake in Cumbôk war and subvert the ulèëbalangship.

As the explanation sketched above, it is evident that the ulëëbalangs' malfeasance in controlling commerce, among other things, did contribute to the tension arising between ulamas and ulèëbalangs, which eventually spurred the two fighting groups to wage the Cumbôk war.

After all, this study refrains from using particular text to work from the specific to general when laying out the principles of commercial policy of uleeëbalangs. In other words, the findings suggest nothing about vilifying the facts about uleeebalangs since we can hardly generalize that the attributes mentioned above about them are also attached to their fellows across many ruled regions in Aceh.

\section{References}

Abott, A. (2008). Library research and its infrastructure in the twentieth century. Windsor Lecture Series 2008.

Agustiningsih, N. (2007). Konflik Ulama-Uleebalang 1903-1946 dan Pengaruhnya terhadap Perubahan Sosial di Aceh. (Undergraduate Thesis). Universitas Sebelas Maret, Surakarta, Indonesia.

Alfian. (1975). The Ulama in Acehnese society: A Preliminary Observation. Southeast Asian Journal of Social Science, 3(1), 27-41.

Alfian, I. (1992). Sastra Perang: Sebuah Pembicaraan Mengenai Hikayat Perang Sabil. Jakarta: Balai Pustaka.

Arif, A. (1946). Disekitar Peristiwa Pengchianat Tjoembok. Koetaradja: Semangat Merdeka. 
Chambert-Loir, H. (2017). Islamic Law in 17th Century Aceh. In Archipel. Études interdisciplinaires sur le monde insulindien, (94), 51-56. https://doi.org/10.4000/archipel.444

Crecelius, D., \& Beardow, E. A. (1979). A Reputed Acehnese” Sarakata” Of The Jamal Al-Lail Dynasty. Journal of the Malaysian Branch of the Royal Asiatic Society, 52(2(236)), 51-66.

Daud, A. (2006). Peristiwa Cumbok di Aceh. Aceh. Dinas Kebudayaan Aceh.

Deraniyagala, S. (2005). The political economy of civil conflict in Nepal. Oxford Development Studies, $33(1), 47-62$.

Dewanto, N. (2011). Daud Beureueh: Pejuang Kemerdekaan yang Berontak. Jakarta: Kepustakaan Populer Gramedia.

El-Ibrahimy, M. N. (1982). Tgk. M. Daud Beureueh: Peranannya dalam Pergolakan di Aceh. Jakarta: Gunung Agung.

Hasjmy, A. (1977). Apa Sebab Rakyat Aceh Sanggup Berperang Puluhan Tahun Melawan Agressi Belanda. Jakarta: Bulan Bintang.

Humphreys, M. (2003). Economics and violent conflict. Cambridge, MA.

Hurgronje, S. (1906). The Acehnese. London: E. J. Brill.

Hussin, N. (2005). Networks of Malay merchants and the rise of Penang as a regional trading centre. Southeast Asian Studies, 43(3), 215-237.

Insider. (1950). Atjeh Sepintas Lalu. Jakarta: Archapada.

Ismail, M. G. (1991). Seuneubok lada, uleëbalang dan kumpeni: Perkembangan sosial ekonomi di daerah batas : Aceh Timur, 1840-1942 = Pepertuinen, uleëbalangs en de kompenie : sociaal-ekonomische ontwikkelingen in een grensgebied: Oost-Atjeh, 1840-1942(Thesis/Dissertation). Rijksuniversiteit te Leiden, Leiden, Netherlands.

Jongejans, J. (1939). Land en volk van Atjeh: Vroeger en nu. Michigan, Amerika: Hollandia Drukkerij.

Kurniawati. (2008). Perang Cumbôk Dan Gerakan Tentara Perjuangan Rakyat (TPR) Di Aceh (Desember 1945 Maret 1946). Jurnal Sejarah Lontar, 5(2), 20-34.

Ratna. (2005). Perang Saudara di Aceh (1945). Hisorisme, 1(21), 29-33.

Reid, A. (1979). The Blood of The People: revolution and the end of traditional rule in northern Sumatra. Kuala Lumpur: Oxford University Press.

Revolusi Desember '45 Di Aceh atau Pembasmian Pengkhianatan Tanah Air. (n.d.). Aceh: Kementerian RI Daerah Aceh.

Safwan, M. (1992). Pahlawan Nasional Teuku Nyak Arif. Jakarta: Balai Pustaka.

Sandelowski, M. (2000). Focus on research methods: Whatever happened to qualitative description? Research in Nursing and Health, 23(4), 334-340.

Siegel, J. T. (1969). The Rope of God. Berkeley and Los Angels: University of California Press.

Sjamsuddin, N. (1985). The republican revolt: A study of the Acehnese rebellion. Singapore: Institute of Southeast Asian Studies.

Sulaiman, M. I. (Ed.). (1990). Hikayat Prang Cumbôk (Fungsinya sebagai Karya Sastra Dan Sumber Sejarah Aceh) De auteur

Tiro, H. M. (1999). Demokrasi untuk Indonesia. Jakarta: Teplok Press.

Uddin, A. T. (2009). Religious freedom implications of sharia implementation in Aceh, Indonesia. U. St. Thomas LJ, 73),47.

Van 't Veer, P. (1969). De Atjeh Oorlog. N.V. Amsterdam: Uitgeverij de Arbeiderspers.

Wong, Y. T., \& Lee, K. H. (2014). Aceh-Penang Maritime Trade and Chinese Mercantile Networks in the Nineteenth Century. Archipel, 871), 173-202. 


\section{Acknowledgement}

Our credits go to Prof. Dr. Arndt Graf, chairman of Southeast Asian Studies Department at GoetheUniversität Frankfurt am Main, and to Prof. Dr. Achmad Nurmandi, M. Sc., director of Jusuf Kalla School of Government Universitas Muhammadiyah Yogyakarta, for the supervision. Our gratitude and appreciation to the Aceh Human Resources Development Agency (BPSDM Aceh) and Deutscher Akademischer Austauschdienst (DAAD) for financial support. 